TECHNICAL NOTES AND MANUALS

\title{
Medium-Term Debt Management Strategy Analytical Tool: Data Preparation Manual
}

Emre Balibek, Tobias Haque, Diego Rivetti, and Miriam Tamene

Monetary and Capital Markets Department, International Monetary Fund

The World Bank

I NTERNATIONAL MONETARY FUND THE WORLD B A N K 
TECHNICAL NOTES AND MANUALS

Medium-Term Debt Management Strategy Analytical Tool: Data Preparation Manual

Ere Balibek, Tobias Hague, Diego Rivetti, and Miriam Tamene Monetary and Capital Markets Department, International Monetary Fund The World Bank

INTERNATIONAL MONETARY FUND THE WORLD BA N K

(International Monetary Fund. Not for Redistribution 


\title{
INTERNATIONAL MONETARY FUND
}

\author{
Monetary and Capital Markets Department
}

\author{
THE WORLD BANK
}

\section{Medium-Term Debt Management Strategy Analytical Tool: Data Preparation Manual}

Prepared by Emre Balibek, Tobias Haque, Diego Rivetti, and Miriam Tamene Authorized for distribution by Tobias Adrian and Ceyla Pazarbasioglu

February 2019

DISCLAIMER: This Technical Guidance Note should not be reported as representing the views of the IMF. The views expressed in this paper are those of the author(s) and do not necessarily represent the views of the IMF and World Bank, their Executive Boards, or management.

\begin{tabular}{|l|l|}
\hline JEL Classification Numbers: & H600, H630, H680 \\
\hline Keywords: & $\begin{array}{l}\text { MTDS, Debt Management Strategy, Debt } \\
\text { Management, Debt Portfolio Cost and Risk Analysis }\end{array}$ \\
\hline Authors' E-Mail Addresses: & $\begin{array}{l}\text { mtamene@imf.org; ebalibek@imf.org; } \\
\text { drivetti@worldbank.org; thaque@worldbank.org }\end{array}$ \\
\hline
\end{tabular}

CInternational Monetary Fund. Not for Redistribution 


\section{TECHNICAL NOTES AND MANUALS}

\section{Medium-Term Debt Management Strategy Analytical Manual: Data Preparation Manual}

This manual provides instructions on preparing debt data for use in the Medium-Term Debt Management Strategy Analytical Tool 


\section{TABLE OF CONTENTS}

INTRODUCTION _____________________________________________________

TYPE OF DATA TO USE __________

DEBT DATA PREPARATION STEPS___ $\underline{\mathbf{8}}$

Step 1: Setting up the "Data Preparation" Excel File_______

Step 2: Assigning Debt Instrument to a 'Representative Instrument' ___________

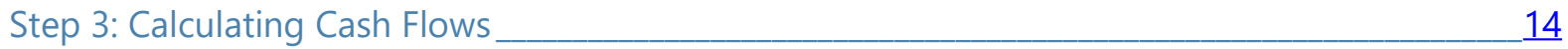

Step 4: Converting Cash Flows from Original Currency to Base Currency ______

Step 5: Aggregating Cash Flows by 'Representative Instruments' _____

Step 6: Creating Charts for the Portfolio Composition ______ 21

\section{TABLES}

1. Original Creditors Grouped by 'Representative Instruments' ___ 10

2. Assigning Instrument Code___ 12

3. From Loans and Creditors to 'Representative Instruments' _____ 13

4. Exchange Rates as at December 31, $2017 \ldots$

5. Cash Flows Aggregated by 'Representative Instruments' ______ 20

\section{ANNEXES}

A. Treasury Bills: Interest Payments and Average Yields____ 22

B. Debt Denominated in Special Drawing Rights____ 24 


\begin{tabular}{ll} 
ADF & African Development Fund \\
AT & Analytical Tool \\
CHF & Swiss franc \\
CNY & Chinese yuan \\
CS-DRMS & Commonwealth Secretariat Debt Recording and Management System \\
DKK & Danish krone \\
DMFAS & Debt Management and Financial Analysis System \\
DOD & Disbursed and Outstanding Debt \\
EDF & European Development Fund \\
EUR & Euro \\
GBP & British pounds \\
IBRD & International Bank for Reconstruction and Development \\
IDA & International Development Association \\
IDB & Inter-American Development Bank \\
IFAD & International Fund for Agricultural Development \\
IMF & International Monetary Fund \\
JPY & Japanese yen \\
KRW & South Korean won \\
MTDS & Medium-Term Debt Management Strategy \\
MTDS AT & Medium-Term Debt Management Strategy Analytical Tool \\
T-bills & Treasury Bills \\
T-bonds & Treasury Bonds \\
UNCTAD & United Nations Conference on Trade and Development \\
USD & United States Dollar \\
UTP & Utopia \\
WB & World Bank \\
XDR & Special Drawing Rights \\
\hline
\end{tabular}




\section{INTRODUCTION}

The objective of the data preparation manual is to guide the preparation of the debt data used in the Medium-Term Debt Management Strategy Analytical Tool (MTDS AT). ${ }^{1}$ This manual will discuss: (i) what type of data are needed to prepare a debt management strategy, and (ii) how to prepare this data for the MTDS AT.

Key inputs to the MTDS AT include accurate data on the total amount of disbursed and outstanding debt (DOD), and detailed information on its financial terms and conditions (for example, currency, maturity period, interest rate, and instrument type). Based on this information, cash flow projections for aggregate interest payments and principal repayments are generated.

This manual assumes that the accuracy of the database has been examined by the analyst, although the process described below will also help to identify gaps and errors in the database. ${ }^{2}$

The MTDS exercise is focused on analyzing the costs and risks (for example, exchange rate, interest rates, and refinancing) of the overall government debt portfolio, which will evolve depending on future funding choices. To this end, aggregation of individual debt instruments into a few representative instruments that capture the important features of alternative financing sources facilitates the analysis. Thus, all debt instruments that have similar characteristicsforeign versus domestic currency denominated, commercial versus concessional interest ratesshould be grouped together. In particular, data preparation involves manipulating and compiling individual debt instruments extracted from the debt recording system into a maximum of 20 representative instruments.

The methodology suggested in this manual should be considered as one of many possible ways of preparing the debt data for the MTDS AT. In particular, its use is suggested in the cases where the debt database is sizeable. However, other methodologies could be valid, provided that the key aggregation criteria—described under Step 2 of this manual—are respected.

The manual should be used in combination with the Excel file MTDS Data Preparation File, which should help visualize how to properly prepare the data. The manual will make references to specific cells and formulas that will correspond to the Excel file. It should be noted that the

\footnotetext{
${ }^{1}$ For more Information please refer to the Medium-Term Debt Management Strategy: Analytical Tool Manual.

${ }^{2}$ Cash flow projections for interest payments and principal repayments associated to debt outstanding and disbursed also determine future gross financing needs. Hence, if the level of the existing debt and its cash flow projections are over- or under-estimated, the assumptions for the medium-term financing needs will be inaccurate and will bias the analysis. Therefore, the first step before conducting the MTDS analysis is to ensure that the debt data is accurate, by reconciling the database with the creditors on a regular basis and ensuring that the database is validated and updated accurately and on a timely basis.
} 
debt dataset utilized in 'MTDS Data Preparation File' is fictitious, and therefore some details that would otherwise be available from debt recording systems are missing. ${ }^{3}$

\section{TYPE OF DATA TO USE ${ }^{4}$}

- Use the debt data for each instrument by debt instrument from the existing data recording system (for example, UNCTAD's Debt Management and Financial Analysis System, DMFAS, the Commonwealth Secretariat's Debt Recording and Management System, CS-DRMS, or in-house database) in the original currency of the loan. The analysis should be undertaken with the latest available data at period end, which can be in calendar or fiscal year.

- Use debt data that is disbursed and outstanding debt (DOD). This excludes contracted debt that is still in the pipeline, since undisbursed debt is not part of existing liabilities. Undisbursed debt should be considered as "new" disbursements when designing portfolio strategies.

- Data should include all financial terms and conditions of the existing debt. At a minimum, data should include the following: creditor's name, loan or securities identification number (ID), currency, first and last date of repayment, grace period, interest rate and type-fixed or variable-(for variable interest rate instruments, the reference rate and the margin have to be separated), total amount of debt outstanding at the end of the period (calendar or fiscal), and end of period exchange rates for all the currencies in the debt portfolio. ${ }^{5}$ It is recommended that as much information as possible is extracted from the debt recording system. ${ }^{6}$

- Cash flow information on principal repayments and interest payments until the final maturity year for every debt instrument.

- The minimum coverage of the debt portfolio should be the external and domestic debt of the central government. ${ }^{7}$

\footnotetext{
${ }^{3}$ The fictitious country, is Utopia, with a currency code UTP.

${ }^{4}$ In compiling data, analysts should refer to the IMF's Government Finance Statistics Manual 2014, which provides guidance on financial assets and liabilities. With regards to liabilities, for the MTDS, loans and securities are the ones applicable.

${ }^{5}$ With regards to currency, some creditors provide choice of currency for repayment of loans, which can be different from the currency in which the debt was contracted. For instance, a debt could be contracted in U.S. dollars, with the creditor providing the option to repay in euros or another currency; in this case, the contract currency should be the U.S. dollar.

6 This will allow the analyst to check for accuracy and consistency, should it become necessary.

${ }^{7}$ Note that the definition of external debt in the context of MTDS is currency-based rather than a residencybased definition.
} 


\section{DEBT DATA PREPARATION STEPS}

Note that the steps described in this manual are also summarized in the Preparation Steps worksheet in the 'MTDS Data Preparation File'.

Preparing the data to use the MTDS AT involves the following steps:

- Step 1: Setting up the Data Preparation Excel File

- Step 2: Assigning Debt Instrument to a 'Representative Instrument'

- Step 3: Calculating Cash Flows

- Step 4: Converting Cash Flows from Original Currency to Base Currency

- Step 5: Aggregating Cash Flows by 'Representative Instruments'

- Step 6: Creating Charts for the Portfolio Composition

\section{Step 1: Setting up the "Data Preparation" Excel File}

- Download central government external debt (denominated in foreign currency) and domestic debt data including the parameters outlined in the Introduction from the debt recording system to an Excel workbook, and create a worksheet called Debt Original

\section{Currency.}

- Create a new worksheet to convert all debt cash flows calculated in the Debt Original Currency worksheet into a common currency, that is, the base currency. Depending on the choice of the analyst, this could be the local currency, UTP, or a major foreign currency such as the U.S. dollar (USD) or the euro (EUR). Name the worksheet using the acronym of the chosen base currency, for example, Debt UTP Debt USD or Debt EUR. In this manual, the USD is used as the base currency for illustrative purposes.

- Create a new worksheet called Representative Instruments FX. This worksheet will be used to define and save information of the chosen representative instruments, including their codes, as well as exchange rates.

- Create a new worksheet called Aggregated UTP or Aggregated USD, depending on the choice of base currency, to summarize cash flows in representative instruments.

- Create a new worksheet called Working Sheet to perform all intermediate/preparatory steps for the data aggregation.

- Create a new worksheet called Charts, to produce charts that show the composition of the debt portfolio by type of currency, interest rate, and creditor. 


\section{Step 2: Assigning Debt Instrument to a 'Representative Instrument'}

\section{What is accomplished in this step?}

In this section each debt instrument will be assigned to a 'representative instrument,' which will represent a group of debt instruments that have similar financial characteristics. To perform this task, the analyst should have a good understanding of the main characteristics of the debt portfolio, including the main creditors (by volume), and the type of financial terms (maturity and grace period; interest rate, including whether fixed or variable) they offer.

A general rule is that debt instruments with different types of interest rates (for example, fixed versus variable rate) cannot be grouped in the same instrument. Also, debt instruments denominated in domestic currency cannot be grouped together with foreign currency denominated instruments. For foreign currency instruments, choose one (or a few foreign currencies, but not more than four) in which debt instruments are predominantly contracted. In this manual foreign currency instruments will be represented by USD.

Frequently used groupings or 'representative instruments' include: multilateral concessional loans, multilateral semi-concessional loans, bilateral concessional loans, bilateral semi-concessional loans, international capital market bonds, syndicated loans, Treasury bonds (T-bonds), and Treasury bills (T-bills) with different maturities.

Go to the worksheet Debt Original Currency and copy the column that includes names of all existing creditors (cells C5:C45). Do not make any changes in this list; keep the names of the creditors as they appear in your database. Paste this information in the worksheet Working Sheet (Step 1 in Preparation Steps worksheet). Use Excel's function Remove Duplicates to create a column that will list all existing creditors once by the original name (Step 2 in Preparation Steps worksheet).

\section{Excel tip: How to use the Excel function 'Remove Duplicates'?}

Highlight pasted column and go to Excel command 'Data' in the upper ribbon on the screen; click on it and select the function 'Remove Duplicates.' If you have a header in the copied column, mark the box "My data has headers." Now execute the function and Excel will display information on how many duplicates were removed.

Analyze the unique set of existing creditors by determining which debt instruments carry similar terms and conditions. Terms and conditions should be similar enough to group debt instruments under the same representative instrument. As an example, the International Development Association (IDA), the International Fund for Agricultural Development (IFAD), and the European Development Fund (EDF) offer loans with long maturities (around 30 years) and highly concessional fixed interest rates, therefore the analyst might consider grouping these loans together and creating an instrument that represents all three existing creditors - 'IDA/IFAD/EDF.'

Loans from the African Development Fund (ADF) have a very particular repayment profile; for this reason, a separate instrument is created for the ADF loans called 'ADF'; instrument 1 in the MTDS AT. Similarly, since index-linked debt instruments require their principal or interest adjusted by the reference rate, instrument 20 in the MTDS AT is dedicated to such instruments. Following 
these examples, assign a representative instrument to each of the existing creditors, and create a table of representative instruments, such as Table 1 below (Step 3 in the Preparation Steps worksheet).

Copy and paste the new table in the worksheet Representative Instruments FX. Then, go to the worksheet Debt Original Currency and insert three new columns - 'Representative Instruments1,' 'Representative Instruments-2,' and 'Instrument Code.' (Columns E, F, and G in worksheet Prepared Debt Original Currency).

In the first column 'Representative Instruments-1' use the VLOOKUP function to assign a representative instrument (from Table 1), to each existing debt instrument listed in the worksheet Debt Original Currency.

\begin{tabular}{|l|l|}
\hline \multicolumn{2}{|c|}{ Table 1. Original Creditors Grouped by 'Representative Instruments' } \\
\hline Original creditor name & Representative Instrument \\
\hline International Development Association & IDA/IFAD/EDF \\
\hline European Development Fund & IDA/IFAD/EDF \\
\hline Int'I Bank for Reconstruction and Devpt. & IBRD/ADB/IDB \\
\hline ADF & ADF \\
\hline ADB & IBRD/ADB/IDB \\
\hline African Development Bank & IBRD/ADB/IDB \\
\hline African Development Fund & ADF \\
\hline Export-Import Bank of Korea & Bilateral \\
\hline IDA & IDA/IFAD/EDF \\
\hline Int'I Fund For Agricultural Development & IDA/IFAD/EDF \\
\hline ABC Bank & Commercial Bank \\
\hline DEF Bank & Commercial Bank \\
\hline Exim Bank of China & Bilateral \\
\hline ISLAMIC DEVELOPMENT BANK & IBRD/ADB/IDB \\
\hline Treasury Bonds_10Y & Treasury Bonds_10Y \\
\hline Treasury Bonds_2Y & Treasury Bonds_3Y \\
\hline Treasury Bonds_3Y & Treasury Bonds_3Y \\
\hline Treasury Bonds_5Y & Treasury Bonds_5Y \\
\hline Treasury Bonds_7Y & Treasury Bonds_5Y \\
\hline Treasury Bills & Treasury Bills \\
\hline
\end{tabular}

\section{Excel tip: How to use the Excel VLOOKUP function to map existing and stylized instruments?}

Go to the worksheet Debt Original Currency (worksheet Prepared Debt Original Currency), cell E5 and type the following formula: =VLOOKUP(C5,'Representative Instruments_FX'! B \$5:\$C\$24,2,FALSE)

This formula looks for the value of cell $\mathrm{C} 5$ (which is a creditor) in the first column of the range 'Representative Instruments_FX'! $\$ B \$ 5: \$ C \$ 24$ (which is the first column Table 1) and then returns the value that is contained in the second column of the range (second column in Table 1) and on the same row as the lookup value in cell $\mathrm{C} 5$.

Now with the correct formula in the first cell of the column, extend (drag) this formula across the whole column (in the worksheet Prepared Debt Original Currency E5: E45). [Note: the vlookup range is fixed!]. 
In the second column called 'Representative Instruments-2' (column F in worksheet

Prepared Debt Original Currency), link the new representative instrument with the interest rate type of the debt instrument. To do this, use Excel function CONCATENATE (columns E and T in

Prepared Debt Original Currency). ${ }^{8}$

\section{Excel tip: How to use the Excel function 'CONCATENATE'?}

=CONCATENATE $($ E5," ","T5)

This formula links the value of cell E5 with the value in the cell T5. Both values are separated by an underscore "_". Now extend (drag) this formula across the whole column.

In the third column 'Instrument code', assign a numerical value to each representative instrument. First, copy the column 'Representative Instruments-2' and paste it in the worksheet Working Sheet (Step 4 in the Preparation Steps worksheet). Use Excel function 'Remove Duplicates' to list each instrument once.

Highlight the copied and pasted column and go to Excel command 'Data' in the upper ribbon on the screen; click on it and select the function 'Remove Duplicates.' If you have a header in the copied column, mark the box 'My data has headers.' Next, execute the function and Excel will display information on how many duplicates were removed. (The output should look similar to Step 5 in the Preparation Steps worksheet).

Now representative instruments are displayed with their interest rate types attached to them (left column in Table 2 below). Some countries may interchangeably use the terms 'fixed' or 'amount' to describe fixed interest rate loans; also, countries use the term 'variable' or 'floating' interchangeably to describe variable interest rate instruments. If countries have such instruments, one code should be used for the representative instrument with the same interest rate type; for example, 'IBRD/ADB/IDB_Fixed' and 'IBRD/ADB/IDB_Amount' should be assigned the same instrument code since both instruments include the same creditors and are fixed-rate loans.

As mentioned before, there are a few rules on assigning instrument codes. ADF loans always should have instrument code 1 . This is because the MTDS AT is programmed to capture specificities of the ADF loan repayment structure under the instrument code 1. Similarly, indexlinked debt instruments, whose principals or coupons are adjusted by an index, should be assigned to instrument code 20.

Next, continue assigning instrument codes to all existing external (foreign currencydenominated) instruments. In the example ('MTDS Data Preparation File'), these are instruments 2 to 6 . If warranted, leave some instrument codes (instruments $7-8$ and $13-20$ as in the example) for new instruments that can be used in the medium-term debt strategy, which are not part of the existing debt portfolio. Then continue assigning codes for domestic instruments, Table 2, second column.

\footnotetext{
${ }^{8}$ An alternative to the CONCATENATE function is using the symbol " $\&$ ". In the example, $=$ CONCATENATE (E5,"_",T5) can also be derived by entering =E5\&"_ \&T5.
} 


\begin{tabular}{|l|c|}
\hline \multicolumn{2}{|c|}{ Table 2. Assigning Instrument Code } \\
\hline Representative Instrument & Instrument Code \\
\hline IDA/IFAD/EDF_Fixed & 2 \\
\hline IBRD/ADB/IDB_Fixed & 3 \\
\hline ADF_Fixed & 1 \\
\hline IBRD/ADB/IDB_Floating & 4 \\
\hline Bilateral_Fixed & 5 \\
\hline Commercial Bank_Fixed & 6 \\
\hline Treasury Bonds_10Y_Fixed & 14 \\
\hline Treasury Bonds_3Y_Fixed & 12 \\
\hline Treasury Bonds_5Y_Fixed & 13 \\
\hline Treasury Bills_Fixed & 11 \\
\hline
\end{tabular}

Once this task is finished, the table in the worksheet 'Representative Instruments_FX' will reflect these codes (as in Table 2). (Step 6 in the Preparation Steps worksheet).

After this, go to the worksheet Debt Original Currency column 'Instrument Code', and use the VLOOKUP function to assign the instrument code from the worksheet Representative Instruments FX Table 2, to each existing debt instrument listed in the worksheet Debt Original Currency.

\section{Excel tip: How to use the Excel function 'VLOOKUP to assign instrument codes'?}

Go to the worksheet 'Debt Original Currency', cell G5 (see column G in Prepared_Debt Original Currency) and type the following formula:

$$
\text { =VLOOKUP(F5,'Representative Instruments_FX'!\$E\$5:\$F14,2,FALSE) }
$$

This formula searches for the value of the cell F5 (which is a representative instrument) in the first column of the range 'Representative Instruments_FX' $\$ E \$ 5: \$ F \$ 14$ (which is Table 2 in the worksheet 'Representative Instruments_FX) and then returns the value that is contained in the second column of this table range (which is the instrument code) and on the same row as the lookup value in cell F5.

Once the correct formula is entered in the first cell of the column, extend (drag) this formula across the whole column.

With these steps, each debt instrument is assigned a representative instrument and a code (as shown in Table 3 below), allowing the aggregation of cash flows by representative instruments.

As mentioned before, multiple foreign currencies (up to four) can be used for representative instruments. This typically occurs when a sizeable portion of the existing portfolio or significant future disbursements are denominated in these currencies. In this case, currency denomination should be included as an additional criterion to identify representative instruments. While the aggregation of all cash flows will be done in a single base currency (Step 5 below), identifying representative instruments by different codes will help when projecting cash flows and formulating debt strategies at a later stage. 
Table 3. From Loans and Creditors to 'Representative Instruments'

\section{Creditor}

International Development Association

International Development Association

European Development Fund

Int'I Bank for Reconstruction and Devpt.

ADF

ADF

$A D F$

$A D F$

$A D F$

$A D F$

$A D B$

$A D B$

$A D B$

$A D B$

$A D B$

African Development Bank

ADF

African Development Bank

African Development Fund

Export-Import Bank of Korea

IDA

African Development Fund

African Development Fund

African Development Fund

African Development Fund

African Development Bank

African Development Fund

African Development Bank

ADF

$A D B$

Int'I Fund For Agricultural Development

ABC Bank

DEF Bank

Exim Bank of China

ISLAMIC DEVELOPMENT BANK

Treasury Bonds_10Y

Treasury Bonds_2Y

Treasury Bonds_3Y

Treasury Bonds_5Y

Treasury Bonds_7Y

Treasury Bills
Representative Instrument -2 Instrument Code

IDA/IFAD/EDF_Fixed

IDA/IFAD/EDF_Fixed

IDA/IFAD/EDF_Fixed

IBRD/ADB/IDB_Fixed

ADF_Fixed

ADF_Fixed

ADF_Fixed

ADF_Fixed

ADF_Fixed

ADF_Fixed

IBRD/ADB/IDB_Floating

IBRD/ADB/IDB_Floating

IBRD/ADB/IDB_Floating

IBRD/ADB/IDB_Floating

IBRD/ADB/IDB_Floating

IBRD/ADB/IDB_Floating

ADF_Fixed

IBRD/ADB/IDB_Floating

ADF_Fixed

Bilateral_Fixed

IDA/IFAD/EDF_Fixed

ADF_Fixed

ADF_Fixed

ADF_Fixed

ADF_Fixed

IBRD/ADB/IDB_Floating

ADF_Fixed

IBRD/ADB/IDB_Floating

ADF_Fixed

IBRD/ADB/IDB_Floating

IDA/IFAD/EDF_Fixed

Commercial Bank_Fixed

Commercial Bank_Fixed

Bilateral_Fixed

IBRD/ADB/IDB_Fixed

T-Bonds 10 YR_Fixed

T-Bonds 3 YR_Fixed

T-Bonds 3 YR_Fixed

T-Bonds 5 YR_Fixed

T-Bonds 5 YR_Fixed

T-Bills_Fixed
2

2

2

3

1

1

1

1

1

1

4

4

4

4

4

4

1

4

1

5

2

1

1

1

1

4

1

4

1

4

2

6

6

5

3

14

12

12

13

13

11 


\section{Step 3: Calculating Cash Flows}

\section{What is accomplished in this step?}

In this section, the analysts will: (i) verify that principal repayments until maturity are accurate;

(ii) calculate outstanding debt obligations for each year until maturity; and (iii) calculate annual interest payments. For fixed-rate debt instruments, interest payments are calculated based on the contracted interest rate, whereas for variable rate loans, interest payments are calculated based on a fixed margin. The reason for capturing initially only the fixed margin for variable rate loans is that the variable portion (the reference rate, for example, the LIBOR rate) will be added later based on forward looking projections in the MTDS AT.

Go to the 'Debt Original Currency' worksheet. In the Prepared Debt Original Currency worksheet, section A5 to X45 contains general terms and conditions of existing debt instruments, while section Z5:BW45 includes information on principal repayments of existing debt instruments until maturity.

Copy the section on debt instruments' general terms and conditions (columns A3 to X45) and paste it twice below the original section (in Prepared Debt Original Currency worksheet, these are sections A46:X88 and A89:X131) to create space for generating the debt outstanding and interest payments at the end of each year.

In most instances, the country's debt database will contain the information on the loan principal repayments until maturity. However, if this information is not available, the analyst can calculate it based on the debt outstanding at the end of a period, the remaining grace period and the last payment date of a loan. Section CC5:DZ45 in the Prepared Debt Original Currency worksheet shows the formula to calculate principal repayments. ${ }^{9}$

If the database contains information on the loan principal repayments, it is necessary to verify that the sum of those principal repayments, equals the DOD at the end of the period, which is the data cut-off date.

Enter a new column (see column $\mathrm{Y}$ in the Prepared Debt Original Currency worksheet). Use the formula:

Equation (1) $\quad$ Outstanding balance t $_{t=0}-\sum_{t=1}^{t=n}$ Principal repayments $=0$

If the formula returns a value different from zero, then the analyst should re-validate the total amount outstanding or the principal repayments.

The next task is to calculate the outstanding balance at the end of each period (in

Prepared Debt Original Currency worksheet, this is done in the section A48:BW88).

\footnotetext{
${ }^{9}$ It is highly recommended that principal repayment cash flows are obtained from debt data recording system as they reflect the most accurate annual repayment profile.
} 
Outstanding balances can be projected on the basis of the initial outstanding balance and the principal payments, by applying the formula presented in Equation (1). ${ }^{10}$

The final task, in this section is to calculate interest payments on a yearly basis (in

Prepared Debt Original Currency worksheet, it is done in the section A91:BW131), using the following formula, Equation (2):

Equation (2) $\quad$ Outstanding balance $_{t} *$ Interest rate $_{t}=$ Interest $_{\text {payments }}$ Int $_{t+1}$

For fixed-rate debt instruments, use the contracted interest rate, for variable rate instruments use only the margin. Use the Excel IF function to distinguish which interest rate to pick depending on whether the debt instrument has a fixed or variable rate. For example, cell Z91 has the formula: $=$ IF $\left(\$ T 91=\right.$ "Fixed ",\$U90,\$W90)*Y47. ${ }^{11}$ The formula looks for the applicable interest rate: for fixed-rate instruments the contracted interest rate is picked up, while for variable ones only the margin is selected.

\section{Calculating the yields for Treasury bills (T-bills)}

It is important to capture the correct weighted average yield on outstanding securities issued with zero coupon/interest rates. T-bills are the most common securities that carry no interest payments. For the MTDS AT, which works on annual basis, T-bills of all maturities are aggregated as one stylized instrument with a maturity of one year. Annex A illustrates how to calculate the appropriate yield for Tbills.

\footnotetext{
10 If there are future disbursement of the same loan, the outstanding balance at $t+1$ should equal the outstanding balance at $t$ minus the principal repayment at $t+1$ plus new disbursement at $t+1$. However, since the debt data input to the MTDS AT should cover only outstanding loans, the new disbursement should not be included.

${ }^{11}$ Please make sure that both fixed interest rates and margins are in expressed in percent.
} 


\section{Step 4: Converting Cash Flows from Original Currency to Base Currency}

\section{What is accomplished in this step?}

In this section, all debt cash flows denominated in different currencies are converted into one base currency, being the local currency, UTP, or foreign currency, such as the USD, euro or any other major currency. To illustrate the conversion, the 'MTDS Data Preparation File', converts cash flows into local currency (UTP), and USD.

Before converting cash flows from the original currency into one representative base currency, (for example, local currency (UTP), USD, or EUR), the analyst needs to make sure that the proper exchange rate for each debt instrument is available to convert to the chosen base currency.

Go to the Debt Original Currency worksheet. In this worksheet insert a new column 'Exchange Rates' (Column I in the Prepared Debt Original Currency worksheet). Copy the column equivalent to 'Tranche Currency' (column H, in the Prepared Debt Original Currency worksheet) and paste it in the worksheet Working Sheet. (Step 7 in Preparation Steps worksheet). Use the Excel function 'Remove Duplicates' to list all currencies in which the existing loans have been contracted. (Step 8 in the Preparation Steps worksheet).

Exchange rates should have the same cut-off date as the debt data. If the debt recording system does not provide end of period exchange rates, these should be sought from local sources (for example, central bank website) or data providers such as Bloomberg or Reuters. Paste the created table in the worksheet Representative Instruments, as in Table 4 below.

\begin{tabular}{|l|r|r|}
\hline \multicolumn{3}{|c|}{ Table 4. Exchange Rates as at December 31, 2017 } \\
\hline Currency & In units of UTP & In units of USD \\
\hline USD & 15.00 & 1.00 \\
\hline XDR & 21.37 & 1.42 \\
\hline EUR & 18.03 & 1.20 \\
\hline JPY & 0.13 & 0.01 \\
\hline DKK & 2.42 & 0.16 \\
\hline CHF & 15.39 & 1.03 \\
\hline IDB & 21.37 & 1.42 \\
\hline KRW & 0.01 & 0.00 \\
\hline UTP & 1.00 & 0.07 \\
\hline
\end{tabular}

In the Debt Original Currency worksheet column 'Exchange Rates' use the VLOOKUP function to assign the correct exchange rate to the tranche currency. Depending on the base currency, the exchange rate should reflect the equivalent value in units of the base currency. If the base currency is the local currency, this will be in units of UTP (as in column 2 of Table 4). If the foreign currency is the base currency, for example, the USD, then this will be the value of currencies in USD (as in column 3 of Table 4).

Use the worksheet created in Step 1, either Debt UTP or Debt USD depending on the choice of the base currency. Copy the content of the entire worksheet Debt Original Currency and paste it in the worksheet, Debt UTP to use the local currency as the base currency, or Debt USD to 
use USD as the base currency. Since the objective is to convert cash flows into the base currency, cash flow identical to the Debt Original Currency need to be recalibrated in Debt UTP or

Debt USD; these are principal repayments, outstanding amounts, and interest payments. In the worksheet Prepared Debt Original Currency these are cells Z5:BW45, Y48: BW88, and Z91:

BW131, respectively.

To recalculate total debt commitments, debt outstanding and cash flows in the base currency, use the exchange rate in Column I and the corresponding cells in the worksheet Debt Original Currency. For example, to calculate cell Z5 in 'Debt_UTP', or 'Debt_USD:'

\section{$=\$ 15 *^{\prime}$ Debt Original currency'!Z5}

If the analyst used the formulae in Equations (1) and (2), Step 3 for Outstanding Amount and Interest Payments, the formulae would be retained in the new worksheet. In this case, converting principal repayments, Z5: BW45 into the base currency, and the Debt Outstanding in the base year Y48: Y88 would suffice.

\section{Special Drawing Rights (SDR) denominated loans}

Loans denominated in Special Drawing Rights carry exposure to the five currencies that make up its composition: U.S. dollar, euro, Japanese yen, Chinese renminbi, and British pound. To convert loans in SDR to the base currency, one should use the SDR exchange rate that is reported in the IMF or World Bank website. Annex B illustrates how to analyze SDR denominated loans. 


\section{Step 5: Aggregating Cash Flows by 'Representative Instruments'}

\section{What is accomplished in this step?}

In this section, the cash flows calculated in the worksheet Debt UTP or Debt USD (for example, principal repayments, outstanding debt and interest payments) will be aggregated by 'representative instruments'.

Use the worksheet created in Step 1 either Aggregated UTP or Aggregated USD' depending on the choice for base currency, and create three tables (Table 5 shows the ones created using the local currency, UTP, as the base currency). In the first table, the principal repayments are aggregated by representative instruments; in the second and third tables, those aggregates are reported for debt outstanding and interest payments, respectively. To create the tables, list the numbers from 1 to 20 , as it is done in the column $D$ in Table 5 . Recall that this is the total number of representative instruments that can be used, with Instruments 1 and 20 by default dedicated for ADF loans and index-linked bonds, respectively. Enter the abbreviation for the domestic currency and a representative foreign currency, for example, USD to represent all foreign currency instruments; the abbreviations, UTP or USD work, as a reminder to distinguish between domestic and foreign currency, while all cash flows are at this stage converted to a single currency. As mentioned above, in the 'MTDS Data Preparation File', for illustrative purposes the aggregation is done both in the local currency, UTP, and USD. For example, if the analyst choses the representative foreign currency to be USD, then the following abbreviations are entered in cells B5 and B6 in Aggregated UTP or Aggregated USD (Table 5 illustrates this). Use the function CONCATENATE to link the instrument number (from column D) with the currency (from cells B5 and B6) in order to obtain the results shown in column E in Table 5. In Aggregated UTP or Aggregated USD worksheet cell E5 the following formula is used = CONCATENATE (\$B\$5," "'D5) to get the currency and the instrument code combination 'USD_1', the exception is instrument 20, where the code IDX is used to identify that index-linked instrument.

Using the SUMIF function aggregate instruments by representative instruments in millions of UTP or USD. The SUMIF function adds up those values in a selected range of data that meets specific criteria (in our case a specific instrument code). The IF portion of the function determines what data meets that specified criteria and the SUM part does the addition.

Use the SUMIF function to aggregate instrument by instrument data by representative instruments on principal repayments, debt outstanding and interest payments for each year.

\section{Excel tip: How to use the Excel function 'SUMIF'?}

In the example, in cell I5 (Table 5) Aggregated UTP worksheet, the following formula can be seen:

=SUMIF ('Debt UTP'! \$G\$5:\$G\$45, Aggregated!\$D5, 'Debt UTP'! Z\$5 : Z\$45)/(10^6)

\section{or Aggregated USD}

= SUMIF ('Debt UTP'! \$G\$5:\$G\$4, Aggregated!\$D5, 'Debt USD'! Z\$5 : Z\$45)/(10^6)

This formula checks if any cell in the worksheet's Debt UTP or Debt USD range $\$ G \$ 5: \$ G \$ 45$ (instrument codes) equals the value set in the aggregation worksheet, Aggregated UTP or Aggregated USD cell D5. For all those cells with values to D5, the formula will look for the corresponding value in the column $Z \$ 5: Z \$ 45$ (Year 2018), which are then all summed up. The value in D5 gives the aggregated amount of principal repayments with code number 1 for year 2018 in UTP millions or USD millions. 
Note that under the check row (red cells), the formula verifies that no cash flow information has been lost in the aggregation process compared to the debt instrument by debt instrument information in the previous worksheet. 


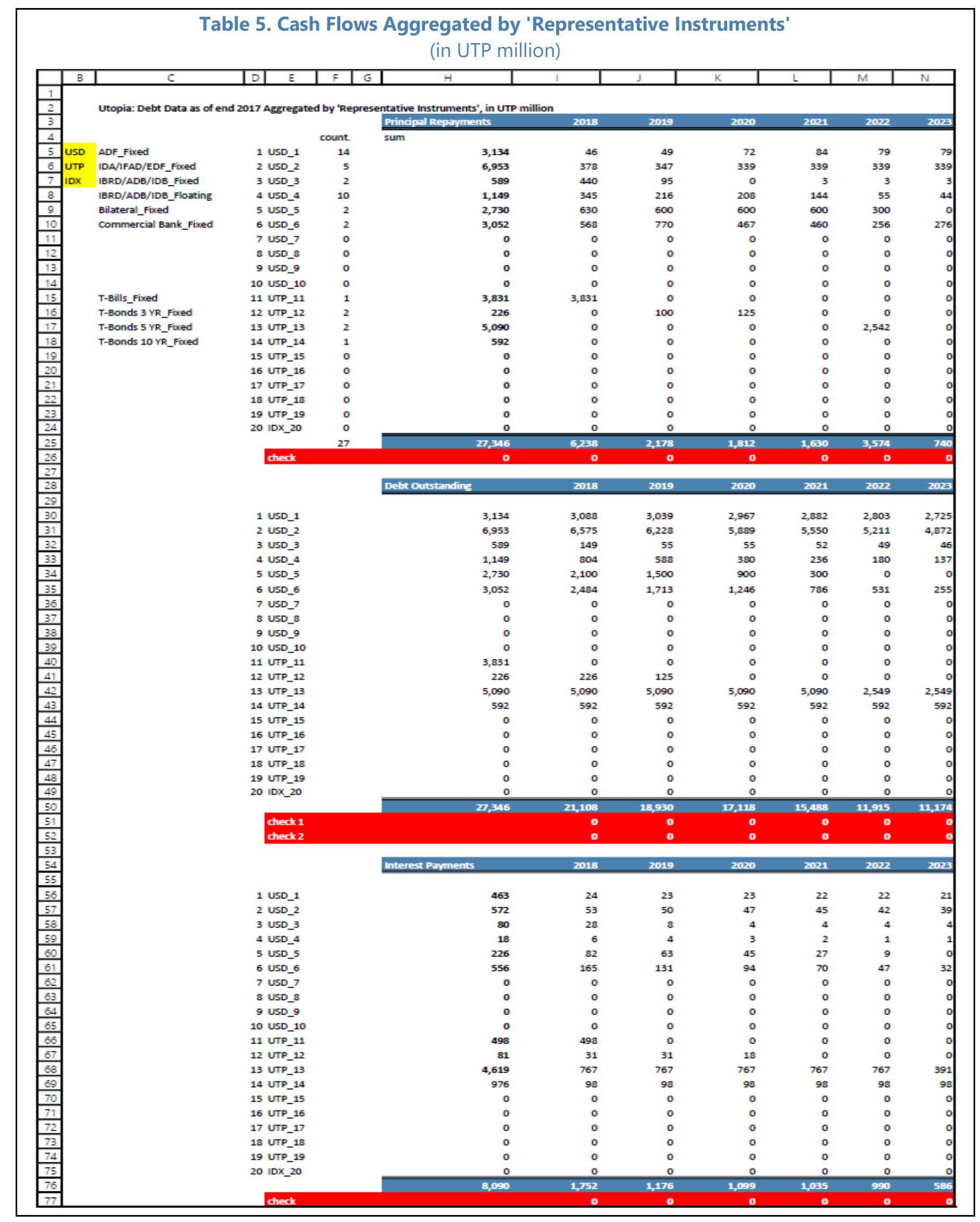




\section{Step 6: Creating Charts for the Portfolio Composition}

\section{What is accomplished in this step?}

In this section, outstanding debt amounts in Debt_UTP or Debt_USD are used to analyze the debt portfolio composition by currency, interest rate and creditor type.

Use the Charts worksheet_created in Step 1. Copy the currencies in the debt portfolio from preparation steps (as in Table 4 above). Using the SUMIF function, aggregate outstanding amounts for each currency for every debt instrument either from Debt UTP or Debt USD depending on the choice of base currency. These data can now be used to create a chart for the currency composition of existing debt. Similarly, charts for interest rate type and creditor composition can be created (by aggregating debt data by interest rate and creditor type). If there are too many creditors, the first step in generating representative instruments from Table 1 that correspond to creditor groups can be used. Similar creditors/instruments can be further grouped together (such as one group of T-bonds instead of individual T-bonds with different maturities). 


\section{Annex A \\ Treasury Bills: Interest Payments and Average Yields}

Since the MTDS AT uses annual cash flows, T-bills are assumed to have a maturity of one year, the shortest maturity. Analysts should take note to correctly record the interest payment and interest rate associated with existing outstanding stock of T-bills. This annex illustrates how to calculate the interest payment from an outstanding stock of T-bills. It also provides guidance on calculating the annualized yield rate to record in the MTDS AT.

For each issuance, users should have information on the tenor, issuance yield rate, and the cash raised. However, at times, the only available information the analyst can easily access, is the discount rate and the face value. The illustrations below cover both scenarios. ${ }^{12}$

Scenario A: Outstanding stock is in cash, whereby yields are recorded; the shaded area shows information available to the analyst (columns $A, B$, and $C$ ). The top row, calculations, shows how to derive interest payments by referencing the columns with known data.

\begin{tabular}{|c|c|c|c|c|c|c|}
\hline \multirow[t]{3}{*}{ Calculations } & & & & $=(C) *[365 /(B)]$ & $=(A) *[(1+C)]$ & $=(F)-(A)$ \\
\hline & (A) & (B) & (C) & (D) & (F) & (G) \\
\hline & $\begin{array}{l}\text { UTP } \\
\text { millions } \\
\text { Cash }\end{array}$ & Days & Percent & Percent & UTP millions & $\begin{array}{l}\text { UTP millions } \\
\text { Interest }\end{array}$ \\
\hline Instruments & Raised & Tenor & Yields & Annualized Yield & Face Value & Payments \\
\hline 3 months & 1,533 & 91 & 3.00 & 12.03 & 1,578 & 46 \\
\hline 6 months & 1,341 & 182 & 7.05 & 14.14 & 1,435 & 95 \\
\hline 12 months & 958 & 365 & 15.35 & 15.35 & 1,105 & 147 \\
\hline
\end{tabular}

Scenario B: Outstanding stock is in cash raised, where discount rates are recorded; the shaded area shows information available to the analyst (columns, A, B, and E). The top row calculations, shows how to derive interest payments by referencing the columns with known data.

\begin{tabular}{|c|c|c|c|c|c|}
\hline \multirow[t]{4}{*}{ Calculations } & & & & \multirow{2}{*}{$\begin{array}{c}=(A) \div[(1-(E)] \\
(F)\end{array}$} & \multirow{2}{*}{$\begin{array}{c}=(F)-(A) \\
(G)\end{array}$} \\
\hline & (A) & (B) & $(\mathrm{E})$ & & \\
\hline & $\begin{array}{l}\text { UTP } \\
\text { millions }\end{array}$ & Days & Percent & Percent & UTP millions \\
\hline & Cash & & Discount & & Interest \\
\hline Instruments & Raised & Tenor & Rates & Face Value & Payments \\
\hline 3 months & 1,533 & 91 & 2.91 & 1,578 & 46 \\
\hline 6 months & 1,341 & 182 & 6.59 & 1,435 & 95 \\
\hline 12 months & 958 & 365 & 13.31 & 1,105 & 147 \\
\hline
\end{tabular}

\footnotetext{
12 Debt analysts should move towards recording yields, which are more readily comparable to other instruments' cost of borrowing.
} 
Scenario C: Outstanding stock is in face value, where yields are recorded; the shaded area shows information available to the analyst, columns B, C, and F. The top row, calculations, shows how to derive interest payments by referencing the columns with known data.

\begin{tabular}{lccccc} 
Calculations & \multicolumn{3}{c}{$=(\mathrm{C}) *[365 /(\mathrm{B})]$} & $=(\mathrm{F}) *[(1-(1 \div(1+(\mathrm{C})))]$ \\
& $(\mathrm{B})$ & $(\mathrm{C})$ & $(\mathrm{D})$ & $(\mathrm{F})$ & $(\mathrm{G})$ \\
& Days & Percent & Percent & UTP millions & UTP millions \\
Instruments & Tenor & Yields & Annualized Yield & Face Value & Interest Payments \\
3 months & 91 & 3.00 & 12.03 & 1,578 & 46 \\
6 months & 182 & 7.05 & 14.14 & 1,435 & 95 \\
12 months & 365 & 15.35 & 15.35 & 1,105 & 147
\end{tabular}

Scenario D: Outstanding stock is in face value, where discount rates are recorded; the shaded area shows information available to the user, columns, B, E, and F. The top row, calculations, shows how to derive interest payments by referencing the columns with known data.

\begin{tabular}{|c|c|c|c|c|}
\hline \multirow[t]{3}{*}{ Calculations } & \multirow{3}{*}{ (B) } & & & \multirow{2}{*}{$\begin{array}{c}=(F) *(E) \\
(G)\end{array}$} \\
\hline & & (E) & (F) & \\
\hline & & Discount & & Interest \\
\hline \multirow[t]{2}{*}{ Instruments } & Tenor & Rates & Face Value & Payments \\
\hline & Days & Percent & UTP millions & UTP millions \\
\hline 3 months & 91 & 2.91 & 1,578 & 46 \\
\hline 6 months & 182 & 6.59 & 1,435 & 95 \\
\hline 12 months & 365 & 13.31 & 1,105 & 147 \\
\hline
\end{tabular}

The weighted average annualized yield is a useful information and an important input for the MTDS AT. To calculate the weighted average annualized yield by using cash raised and annualized yield for each tenor (for example from Scenario A, multiplying columns (A) and (D) and dividing the result by the sum of column $(A)$ ). For cases similar to scenarios $C$ and $D$ where outstanding stock is in face value, users should calculate the cash raised by subtracting interest payments from face value, then working out the yields $=($ Face Value - Cash Raised $) \div$ Cash Raised. 


\section{Annex B \\ Debt Denominated in Special Drawing Rights}

Loans from the major multilateral institutions are often denominated in special drawing rights (SDRs). The value of the SDR is based on a basket of five major currencies, the U.S. dollar (USD), the euro (EUR), the Chinese renminbi (RMB), the Japanese yen (YEN), and the British pound sterling (GBP). The SDR currency value is calculated daily and information can be accessed on the IMF and World Bank websites. ${ }^{12}$

While countries can agree with creditors the currency for debt service payments, SDR loans give rise to exchange rate risk exposure originating from the five underlying currencies.

SDR denominated loans, existing and potential financing, should be treated as follows:

- For existing debt, analysts should find the SDR exchange rate on the appropriate date to convert SDR loans into the major foreign currency used in the AT (for example, USD or euro), and convert further into local currency if existing debt data are entered in local currency, and

- For potential financing, use the major currency as opposed to SDR, for such instruments, while keeping in mind that the instruments pose exchange rate risk to five currencies.

In analyzing SDR denominated loans, the following illustration could be useful. Consider the following example:

As at the end of base year (end-Dec 2017), the aggregate size of SDR loans (the currency code for SDR is XDR) is: XDR 315 million.

The first step is to obtain the weighting (column B) and exchange rate (column C) information. Note that the weightings are reviewed every five years, so the next revision is not until September 2021.

\begin{tabular}{|c|c|c|c|}
\hline $\begin{array}{l}\text { (A) } \\
\text { Currency }\end{array}$ & $\begin{array}{c}\text { (B) } \\
\text { Weighting }\end{array}$ & $\begin{array}{c}(\mathrm{C}) \\
\text { Exchange Rate }\end{array}$ & $\begin{array}{c}=1 /(C) \\
\text { (D) } \\
\text { FX Per 1 USD }\end{array}$ \\
\hline$C N Y^{/ 1}$ & $10.92 \%$ & 9.273 & 0.154 \\
\hline EUR & $30.93 \%$ & 1.187 & 1.199 \\
\hline GBP & $8.09 \%$ & 1.054 & 1.351 \\
\hline JPY & $8.33 \%$ & 160.785 & 0.009 \\
\hline USD & $41.73 \%$ & 1.424 & 1.000 \\
\hline
\end{tabular}

12 Details on SDR are available on the IMF website. 
Then:

- to convert the XDR 315 million into USD, simply multiply by 1.424 or euro by 1.187 ;

- to understand the exchange rate risk exposure, first calculate the SDR amounts exposed to each currency. This implies multiplying XDR 315 million by the weighting of each currency, and then applying the corresponding exchange rates:

Exposure to the underlying five currencies in XDR

\begin{tabular}{lr} 
Currency & XDR millions \\
\hline CNY & 34 \\
EUR & 97 \\
GBP & 25 \\
JPY & 26 \\
USD & 131 \\
\hline Total & 315
\end{tabular}

- the exposure in each currency can be calculated by applying the exchange rate in column (C) above.

\begin{tabular}{lrr}
$\begin{array}{l}\text { Exposure to each currency in its } \\
\text { own denomination }\end{array}$ & $\begin{array}{r}\text { Equivalent in } \\
\text { XDR }\end{array}$ \\
& millions & millions \\
\hline CNY & 319 & $=34$ XDR \\
EUR & 116 & $=97$ XDR \\
GBP & 27 & $=25$ XDR \\
JPY & 4,220 & $=26$ XDR \\
USD & 187 & $=131$ XDR
\end{tabular}

- If one multiplies the exchange rates in column (D), against the result above, the aggregate should equal to the XDR 315 million multiplied by 1.424 .

Exposure to each currency in its

Equivalent in own denomination

USD

\begin{tabular}{lrr} 
& millions & millions \\
\hline CNY & 319 & $=49$ USD \\
EUR & 116 & $=139$ USD \\
GBP & 27 & $=36$ USD \\
JPY & 4,220 & $=37$ USD \\
USD & 187 & $=187$ USD \\
& & $=449$ USD \\
XDR & 315 & $=449$ USD
\end{tabular}


TNM/18/XX

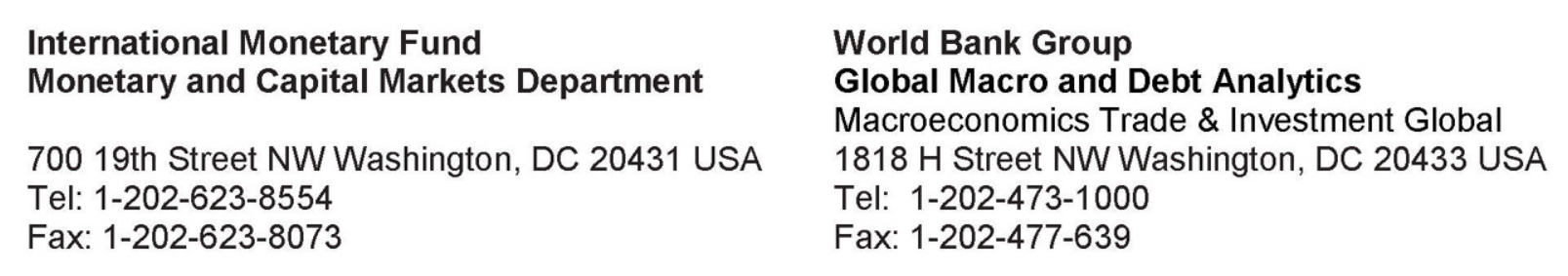

